THE JOURNAL OF PHILOSOPHICAL ECONOMICS:

REFLECTIONS ON ECONOMIC AND SOCIAL ISSUES

Volume XIV Issues 1-2

Spring-Autumn 2021

ISSN: $1843-2298$

EISSN: $1844-8208$

Publication date:

20 November 2021

Paper format: $16.5 \times 23.5 \mathrm{~cm}$

Copyright note:

Authors retain unrestricted copyright and all publishing rights in compliance with the Creative Commons license CC BY-NC-SA.
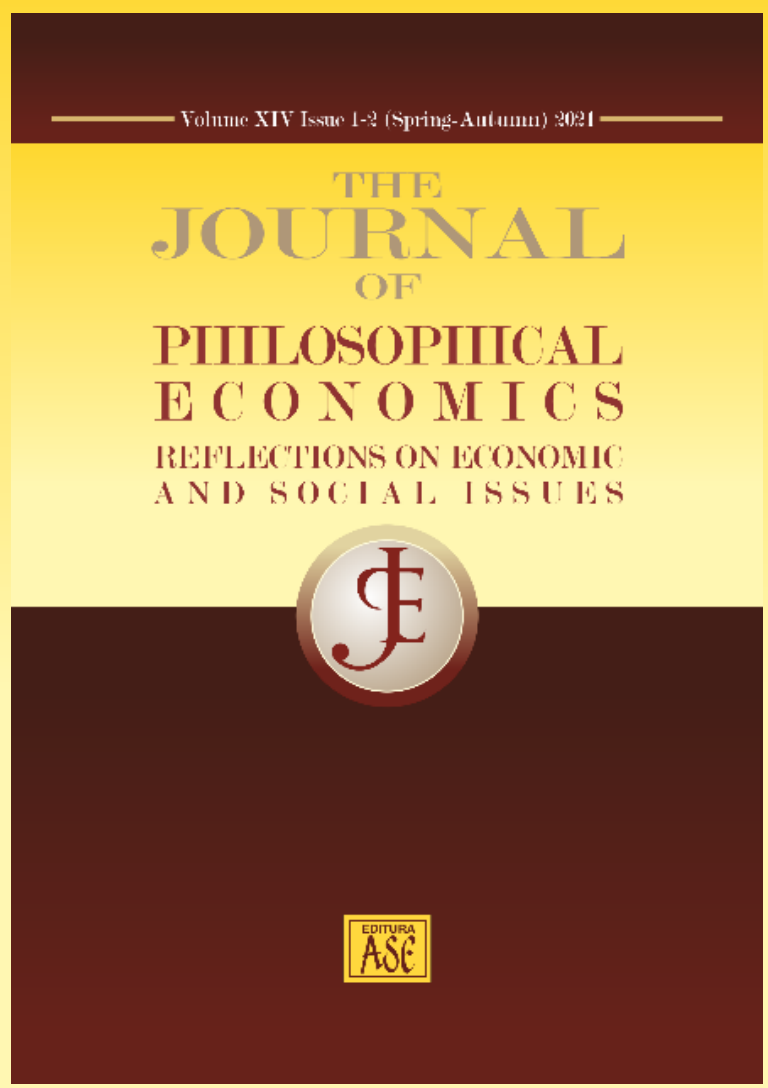

\title{
Method and scope in Joseph A. Schumpeter's economics: \\ a pluralist perspective
}

Turan Yay 


\title{
Method and scope in Joseph A. Schumpeter's economics: a pluralist perspective
}

\author{
Turan Yay
}

\begin{abstract}
This study aims to evaluate the ideas on the scope and method of economics of Joseph Schumpeter who is one of the important economists of the 20th century. The study consists of four sections: In the first section we underline the interesting points of his life to understand the roots, background, or 'vision' of his thought system. In the second section, we will examine his methodological views that he asserted in his first (but translated into English only in 2010) book. Third section will be concerned with his 'analysis of economics' which refers to his critics of Leon Walras's general equilibrium analysis (as static) and his own alternative (dynamics analysis of capitalist economies) about the central subject matter of economics. In the fourth section we will treat his approach about the development/evolution process of economic thought in time. The study concludes with a brief assessment: Schumpeter is one of the rare economists who can build his own thought system in the history of economics, and he embraced a pluralist perspective in the field of the methodology of economics.
\end{abstract}

Keywords: Schumpeter; methodology; economic development; sociology of science

\section{Introduction}

Joseph A. Schumpeter highlights two points in the preface of his book Theory of Economic Development (TED), which was published in English for the first time in 1934. First, he indicates that the book was originally published in 1911 in German under the title Theorie der wirtschaftlichen Entwicklung and that his efforts to develop 'the general framework of the analysis of the purely economic features of capitalist society' in this book are based on his Habilitationsschrift titled Das Wesen und der Hauptinhalt der theoretischen Nationalökonomie (The Nature and Essence of Theoretical Economics) Received: 5 February 2021 
Yay Turan (2021), Method and scope in Joseph A. Schumpeter's economics: a pluralist perspective, The Journal of Philosophical Economics: Reflections on Economic and Social Issues, XIV (1-2), 63-107

(TNETE), which was published in 1908. Second, he indicates that TED is a translation of the second edition of the German original from 1926, and that in this edition, he removed the seventh/final chapter included in the first edition and he re-authored the contents of the seventh chapter and distributed these contents among the second and sixth chapters. This chapter titled 'The Economy as a Whole' (Das Gesamtbild der Volkswirtschaft) had stayed in the dark for a long time for economists who were literate in English but did not speak German. However, some economists who were conducting various studies for evaluating the publications of Schumpeter claim that this chapter ('the lost seventh chapter') is significant for understanding his thought system. This chapter was translated into English by Ursula Backhaus and published in 2002 (Schumpeter 1911/2002), and several papers were authored for evaluating this piece before and after the translation (Shionoya 1990a and 1997; Peukert 2003; van Meerhaeghe 2003; Mathews 2007).

We may easily say that almost every social scientist has heard the name of Schumpeter and his book titled Capitalism, Socialism and Democracy (CSD) and the concept of 'creative destruction' he used in this book. On the other hand, economists know very well his 'The Theory of Economic Development' which is called 'one of the classical economics texts of the 20th century' (McCraw 2007, p.67) and 'History of Economic Analysis' (HEA) which is known as the 'magnum opus' of the history of economic thought. In fact, the first book by Schumpeter and its seventh chapter are very significant both because they are a real contribution to economic thought and also for understanding his own system of thought. Schumpeter laid the foundations for his system of thought in this book, and he maintained this main thesis of his both by applying it to certain topics and by improving it according to the current developments in his subsequent books. However, in order to fully understand Schumpeter's opinions on the scope and method of economics, one must also refer to his methodological views in his book TNETE (1908/2010), which he had published before this study, and to his views on the development process of the history of economic thought in his book HEA (1954/1986), which he published later.

In this paper we show that the methodological views of Schumpeter are pluralistic in the modern sense based on a comprehensive evaluation of all his works. In the first section, we will address the foundations of Schumpeter's 
Yay Turan (2021), Method and scope in Joseph A. Schumpeter's economics: a pluralist perspective, The Journal of Philosophical Economics: Reflections on Economic and Social Issues, XIV (1-2), 63-107

system of thought. In the second section, we will address his methodological views in his book TNETE (1908/2010), which form the backbone of his subsequent works. In the third section, we will try to reveal Schumpeter's concept of economics based on TED and the seventh chapter. In the fourth section, we will try to evaluate his views where he addresses the process of development of the history of economic thought within the context of the sociology of science. The paper will conclude with a brief evaluation.

\section{Joseph Schumpeter: a maverick, enigmatic and idiosyncratic economist}

Schumpeter had started his education in economics in the early 20 th century at the University of Vienna. In those years, The University of Vienna was the centre of Austrian School of Economics (ASE), which received international recognition through its involvement in the significant economic discussions and is accepted as a separate paradigm in economics (Shionoya 1997, p.15). Meanwhile, Carl Menger (1840-1921), the founding father of the School, retired; and Schumpeter took lectures from economists such as Eugen von Böhm-Bawerk (1851-1914), Friedrich von Wieser (1851-1926), Eugen von Philippovich (1858-1916) and Karl Thedor von Inama-Sternegg (1843-1908) (statistician), who are called as the second generation (Swedberg 1991, 1993; Shionoya 1996; McGraw 2007).

Above all, it should be emphasized that the process of undergraduate and graduate studies, during which Schumpeter shaped his views, corresponded to those years in which Vienna turned into a cultural and scientific centre (See Zweig 2013, Schulak and Unterköfler 2011, Janik and Toulmin 1973), and also to the atmosphere of the ongoing methodological pluralism; diverse and fervent discussions on the scope and method of economics (Swedberg 1993, p.23, Shionoya 1997). First of these controversies is between the proponents of the Austrian School and Marxists, which would later be named in the literature as the Socialist Calculation Debate. The second is the 'Great Methodology Debate' (Methodenstreit) between the Austrian School of Economics (Menger) and the German Historical School, which was the dominant approach in economics in the majority of Central Europe. 
Yay Turan (2021), Method and scope in Joseph A. Schumpeter's economics: a pluralist perspective, The Journal of Philosophical Economics: Reflections on Economic and Social Issues, XIV (1-2), 63-107

Schumpeter's view that understanding the economic activities of humans and economic change/development processes of societies is only possible by addressing almost every aspect of the issue has been shaped and matured in him since the years of his Habilitation study. We can see this clearly on the line stretching from the famous seventh chapter of TED (Economy as a Whole) to the first chapter of HEA: economics is a whole comprised of four compartments (Theoretical Economics, History of Economics, Statistics and Economic Sociology), which are related to each other, but which cannot be reduced to any one of these. Schumpeter indicates that this concept of economics corresponds to the concept of economics used by Alfred Marshall since 1890 in the British world of economics and to the concept of Social Economics (Sozialökonomie), the best example of which may be seen in Max Weber (1949) in the German Economics Tradition (Schumpeter 1954/1986, p.19).

Second, Schumpeter's view of always being original by trying to understand opposing views or thoughts where other aspects of the concrete phenomenon can be found was formed during his university years and gradually turned into a methodological pluralism view (Machlup (1953) calls this approach 'methodological tolerance'). As a person who grew up in the Austrian School, Schumpeter's interest in the theory of the evolution of societies of Karl Marx and in the 'applicability of socialism in the concrete world' must be considered in this context. In fact, the inseparable attribute of his own professors, himself and his successor Austrian School generations is the ongoing theoretical and practical discussions with the Marxists. It must be stated here that the Marxists with whom they were discussing were not very far away indeed: While one of the professors of Schumpeter and Mises, namely Carl Grünberg (1861-1940), was a Marxist, it is well known that many Marxist students (Max and Friedrich Adler, Otto Bauer, Karl Renner, Julius Tandler, Emil Lederer, Robert Danneberg, Julius Deutsch, and Rudolf Hilferding) were accompanying Mises and Schumpeter in the lectures of Böhm-Bawerk (Schulak and Unterköfler 2011).

The beginning of the discussion of Austrian School of Economics with the Marxists dates to a little later than the 1870 s, the period that was named as the years of the marginal revolution, in which Carl Menger established the Austrian School of Economics. Böhm-Bawerk criticized the labor theory of 
Yay Turan (2021), Method and scope in Joseph A. Schumpeter's economics: a pluralist perspective, The Journal of Philosophical Economics: Reflections on Economic and Social Issues, XIV (1-2), 63-107

value based on the subjective (marginal utility) theory of value in his book called Capital and Interest (1884) and discussed with economists such as Heinrich Dietzel (1857-1935) and Robert Zuckerkandl (1856-1926). BöhmBawerk directly criticized the system of Karl Marx in his book called Karl Marx and the Close of His System (1896), which he authored about ten years after that. In the 1910s (these are the years during which the impact of socialist thought was very vivid in Russia and Austria, as we have stated above), while the focus of the discussion shifted from theory (labor theory of value versus marginal utility theory of value) to practice (the applicability of socialism in the concrete), the University of Vienna was again the leading school among those where socialism was being discussed at the academic level (Swedberg 1991, 1993). In this context, Böhm-Bawerk suggested that the concept of interest was a concept that is above the systems (See Böhm-Bawerk 1891/1930). On the other hand, Wieser argued that the importance and necessity of the market system is independent of the social organization in the problem of resource allocation based on the concept of marginal utility and natural value and highlighted the necessity of the market organization also for the socialist systems (Ekelund and Hebert 1990, pp.333-334). In fact, starting from this point, the discussion with the Marxists proceeded to the stage called 'Socialist Calculation Debate' as we have mentioned above. Ludwig von Mises from the second generation of the school (Schumpeter's friend) and Friedrich August von Hayek from the next generation brought up a considerable criticism of the applicability of socialism pursuing their professors' stance (for an evaluation see Lavoie 1985) while Schumpeter had a more favourable stance about the applicability of Marxism during and after his student years. As early as in his college years, Schumpeter, together with his Marxist friends such as Otto Bauer and Rudolf Hilferding, was organizing meetings on socialism while at the same time following Böhm-Bawerk's lectures. This friendship would then bring Schumpeter to the position of a member of the German Socialization Commission in 1918-1919 and then to the position of Austrian Minister of Finance at the Coalition Government formed by the Social Democratic Party, the Christian Social Party, and the Catholic Conservative Parties (see Haberler 1951, Swedberg 1991). 
Yay Turan (2021), Method and scope in Joseph A. Schumpeter's economics: a pluralist perspective, The Journal of Philosophical Economics: Reflections on Economic and Social Issues, XIV (1-2), 63-107

Although the Austrian School was not interested in mathematics, Schumpeter took special math courses during his university years and published his first academic work on this subject: 'The Mathematical Method in Theoretical Economics' (1906) (Über die mathematische Methode der theoretischen Ökonomie) (Machlup 1951, p.95). In addition, the Austrian School adopted methodologically the apriorism and argued that the theories do not need to be tested since they are automatically correct, while the title of Schumpeter's 'Habilitation Lecture' was 'The Verification of Abstract Theorems by Statistics' (Swedberg 1991). Schumpeter, who always called himself a 'theoretical economist', argued that the use of mathematical, statistical, and econometric techniques in economics would be useful and that the theories should always be empirically tested (Schumpeter 1908/2010, p.389). Indeed, he pioneered the founding and became the first President of the 'American Econometric Society' in 1930. He taught mathematics and statistics at the Universities of Bonn and Harvard where he worked. We can summarize Schumpeter's views on the importance of mathematical/statistical techniques for economics with the two quotations we will make; the first one from himself and the second from one of his biographers (Schumpeter 1933, p.5; McCraw 2007, p.218): 'We do not impose any credo -scientific or otherwise-, and we have no common credo beyond holding: first, that economics is a science, and secondly, that this science has one very important quantitative aspect. We are no sect. Nor are we a "school." (...) Nothing is farther from our minds than any acrimonious belief in the exclusive excellence of mathematical methods, or any wish to belittle the work of historians, ethnologists, sociologists, and so on. We do not want to fight anyone, or, beyond dilettantism, anything. (...) economics is the most quantitative, not only of "social" or "moral" sciences, but of all sciences, physics not excluded.'

'Schumpeter believed in the necessity of math in economics, but he was too great a thinker to believe in numbers and equations alone. For him, algebra and calculus could never entirely capture the far-reaching complexity of life. Throughout his career, he advanced the cause of math while always also advancing the integration of history, sociology, and psychology into economics as well - without feeling any sense of contradiction.' 
Yay Turan (2021), Method and scope in Joseph A. Schumpeter's economics: a pluralist perspective, The Journal of Philosophical Economics: Reflections on Economic and Social Issues, XIV (1-2), 63-107

In this context, the subject of his Habilitationsschrift which he published in 1908 was the discussions around the nature and essence as well as the method of economics, which the Austrian School made with the Marxists (Marx's System versus Böhm-Bawerk and Wieser) and the proponents of the German Historical School (Menger versus Schmoller): The Nature and Essence of Theoretical Economy (1908). Here, Schumpeter's behaviour is interesting (again): He opposed the German Historical School that argued that 'a general theory of a human's economic behaviour cannot be made, and that economics consists of a whole set of information on the historical observations of societies' and suggested that economics is a theoretical science as the Austrian School defended. The core of his theoretical framework against the German Historical School, however, was not the subjective value theory of the Austrian School of Economics, but the General Equilibrium Theory developed by Leon Walras of the French/Lausanne School of Economics. This does not mean, however, that Schumpeter has completely broken away from the Austrian School; on the contrary, he attempted to develop this basis using the theoretical framework of his teacher, Wieser (from static equilibrium theory of capitalism to dynamic evolution theory of capitalism) (for a similar view see Hebert and Link 2006, p.97, Shionoya 1997, pp.26-30).

On the other hand, while Schumpeter opposed the German Historical School, he emphasized the importance of the economic history and economic sociology for economics, which is also emphasized by the German Historical School, in almost all his works. Schumpeter has always maintained a close interest in the views of the school (see Swedberg 1991, pp.92-93; Shionoya 1997, Chapter 8, Shionoya 2000). In our view, the significance of the historical and sociological aspect that Schumpeter emphasized in his economic analysis should be perceived, maybe in a more comprehensive manner, as a feature of the German Tradition of Economics that could not be reduced solely to the German Historical School (for a similar view, see Mathews 2007, p.85). In other words, the perception of 'economics as a set of inductive information about the historical and sociological characteristics of humans' economic behaviours' is one, and its perception 'as a science that develops theoretical frameworks for economic behaviour of humans based on the historical, sociological and cultural aspects of the society and compares these with the real world' is another 
Yay Turan (2021), Method and scope in Joseph A. Schumpeter's economics: a pluralist perspective, The Journal of Philosophical Economics: Reflections on Economic and Social Issues, XIV (1-2), 63-107

approach. What Schumpeter did here was exactly to adopt and develop the approach of his teacher, Wieser (which was expressed in the name of his book): Social Economics (Wieser 1927). In this book, Wieser suggests that in an ideal state, (in a simple economy, as Wieser states), the economic evolution of a society would be determined by two important features of the human nature (power and leadership) developing within the economic-social-cultural relations of humans based on the comparison between the determinants of value and its economic and sociological aspects and the actual conditions of a society's historical evolution (Ekelund and Hebert 1990, p. 337). Wieser divides social development into layers of economic, social, and political affairs and assigns the most important role in the development of the economic system to the relationships between the power blocs formed by businessmen and workers. For those who have read Schumpeter but have not read Wieser, this idea would not sound too unfamiliar. At this point, Schumpeter would take an important step towards developing the analysis of his teacher with his theory of entrepreneurship (and by emphasizing the innovativeness and leadership traits of the entrepreneur) assuming neither the capitalist nor the workers as the driving force of social development without denying the importance of historical and sociological aspects. In this sense, Schumpeter's effort was to establish a framework at the intersection of the Walrasian General Equilibrium Theory, the Austrian School, and the German Historical School (by also emphasizing the importance of Marx's theory of social change) (for a similar view, see Hebert and Link 2006, p.97). We can also express this attempt with the title of the famous seventh chapter: 'Economy as a Whole.'

We can say that Schumpeter rose fast in his academic life and became a renowned Professor at a young age following a lively and productive period. In the five years that followed his Habilitationsschrift (1906), he became the youngest scholar in Austria to receive professorship (in Graz University) thanks to his three books on the methodology of economics (1908/2010), economic theory (1911) and the history of economic thought (1912/1954) (Swedberg 1993).

In 1932, when Schumpeter started as a professor at Harvard University in the USA, he was an economist who followed the world economic literature closely thanks to the six languages he spoke and was an economist who was, so to 
Yay Turan (2021), Method and scope in Joseph A. Schumpeter's economics: a pluralist perspective, The Journal of Philosophical Economics: Reflections on Economic and Social Issues, XIV (1-2), 63-107

speak, on the production possibility frontier of the economic knowledge of his period. Schumpeter continued to teach here until the end of his life and published his second trilogy (in addition to his other publications) during his years in the USA: Business Cycles (1939), Capitalism, Socialism and Democracy (1943/2003) and History of Economic Analysis (1954/1986) which was published after his death (Swedberg 1993).

What we want to mention briefly here is that a significant continuity may be observed between Schumpeter's trilogy that he authored in Europe at a young age and his second trilogy he authored in the United States at a more mature age. In other words, the same concept of economics is developed and presented (again) in different contexts: According to Schumpeter the main subject matter of economics is to explain the economic change (or evolution) process of capitalist societies. He suggested two models about this problematique.

In the first model included in TED Schumpeter produced a purely economic and endogenous explanation of the economic development in capitalist order in the long run. According to the first model (called as Schumpeter Mark I) the key figure is the entrepreneur with innovative activities because he is the persona causa of economic development. The entrepreneur is important both for making the static equilibrium analysis dynamic and understanding the capitalist change process in the real world. There is no place for the entrepreneur in the hypothetical neoclassical equilibrium model. However, in his model that aims to explain the real world, the importance of the entrepreneur may be understood when we want to address change, the dynamic process of disturbing the equilibrium more clearly. The entrepreneur is especially important for spontaneous, internal to the system and discontinuous changes in the industrial sector. In this context, the first function of the entrepreneur is to be an innovator and make "new combinations (...) by employing existing means of production differently, more appropriately, more advantageously' (Schumpeter 1934, p.132). The second function of the entrepreneur that is inseparable from innovator is leadership, and it refers to 'breaking up old and creating new tradition' that is not only in economic field but also in moral, cultural and social fields: '[In] economic life every step outside the boundary of routine has difficulties and involves a new element. It is this element that constitutes the phenomenon of leadership' (Schumpeter, 
Yay Turan (2021), Method and scope in Joseph A. Schumpeter's economics: a pluralist perspective, The Journal of Philosophical Economics: Reflections on Economic and Social Issues, XIV (1-2), 63-107

1934) [1]. Schumpeter also used this model to explain the short-term crises of capitalism (business cycles) (Schumpeter 1939).

The second model (Schumpeter Mark II) included in CSD is, in essence, an adapted version of the model in TED with some changes based on the concrete developments in the capitalist economies of the post-World War II period. Here, the emphasis shifted from the entrepreneur to the innovative activities of the large firms and their creating barriers to entry to new entrepreneurs and small firms. (Malerba and Orsenigo 1995). The difference is that in the first model there is no negative expectation about the end of entrepreneur-based economic change, whereas there is the prediction that this will lead to the end of capitalism in CSD (which would not be confirmed historically in the following years). Of course, HOEA is also an extended version of DAM, authored during the years of mastery (See Elliot 1983; Osterhammel 1989, p.106).

\section{Schumpeter's methodological views: methodological pluralism}

Schumpeter's complete works that cover almost all fields of economics (see Swedberg 1991 and 1993:5) reveals 'A Grand Design', which has a specific purpose from an interdisciplinary perspective (Haberler 1951; Shionoya 1997, 2012; Bögenhold 2018a): The theoretical, historical, and statistical analysis of the process of capitalist socio-economic and cultural change. The title of this project, alone, gives us an idea at the first glance about his main problematic and his view of the interaction of economics with other related disciplines. However, to understand Schumpeter's views on economic methodology in more detail, we need to look at his first book which is based on his Habilitationsschrift: The Nature and Essence of Economic Theory (1908/2010).

In the foreword of his book, Schumpeter begins with an interesting statement, emphasizing the similarity of discussions on the nature and the production process of scientific knowledge (epistemology and methodology) with the discussions that may be observed in the social relations of people: "To understand is to forgive. Better even: Whoever understands sees that there is nothing one has to forgive. And that is also true in the field of knowledge.' 
Yay Turan (2021), Method and scope in Joseph A. Schumpeter's economics: a pluralist perspective, The Journal of Philosophical Economics: Reflections on Economic and Social Issues, XIV (1-2), 63-107

(Schumpeter 1908/2010, p.ix). This interesting expression of Schumpeter can be interpreted in two ways. The first is for his teachers at the Austrian School where Schumpeter was raised: he hopes they will be persuaded when he explains why he disagrees with their methodological point of view. In this case, there will be no longer any issues for forgiveness (or apology). The second interpretation, on the other hand, is that he is criticizing the level (low quality) of the methodological debates among economists, implies that the debates resemble partisan fights between ordinary people or politicians, and criticizes the 'intolerance' of the parties (Schumpeter 1908/2010, p.4): 'the discussion about methods in our field is characterized by such a high level of intolerance towards the viewpoint of the opponent, that people do not even know their approaches and findings.'

According to Schumpeter, these disagreements arise from the fact that economics or social sciences are not sufficiently developed (with Thomas Kuhn 1962/1996)'s expression, 'since they have not yet established their dominant paradigm'). Schumpeter expresses his own view on the subject as follows (1908/2010, p.x): 'We want to understand, not fight; learn, not criticize; analyze and find what is correct in each sentence, not just simply accept or dismiss. (...) there are absolutely no dichotomies, in the sense that one might be worthless and the other one "correct." In this way we do not share the partiality of most economists, but are absolutely willing to do justice to everybody, as long as we understand them. (...) we do not want to be part of it and rather investigate in each separate case, whether the one or the other methods of investigation should be preferred. This way, we will not get to an all-encompassing answer but to separate ones for each individual case.'

Schumpeter immediately thereafter states that he has no dogmas neither in science nor in method or in politics, and that his sole purpose is 'understanding'. For this purpose, he underlines two points: firstly, not hesitating to use whichever method and approach is appropriate for the subject that is addressed (regardless of its origins or who told it) (he says, 'I am dealing with ideas, not with people'); secondly, however, looking at their dogmatichistorical backgrounds (visions) to fully understand the theorems (Schumpeter 1980/2010). 
Yay Turan (2021), Method and scope in Joseph A. Schumpeter's economics: a pluralist perspective, The Journal of Philosophical Economics: Reflections on Economic and Social Issues, XIV (1-2), 63-107

Based on these points of view, we can describe Schumpeter's approach (1908/2010) as methodological pluralism (see, Swedberg 1993; Ebner 2000). But pluralism here is not a methodological pluralism in the sense of defending the necessity of multiple criteria (simplicity, consistency, explanatory power, predictability, refutability) rather than a single criterion (falsification) (methodological monism) in separating a good theory from a bad theory as in the 1970s and 1980s (see Caldwell 1982; De Marchi 1988). This refers to a methodological pluralism in the sense that historical approach, mathematics, or statistics are employed according to the specific instance or different theories are freely adopted within existing theories (e.g., Walrasian general equilibrium analysis rather than the Austrian School). It would be wrong to argue that the method appropriate for a specific field is universal and applicable in all areas (Schumpeter 1908/2010, p. ivx; 1991a, p.285).

Schumpeter stated that his objective was to answer the questions about the subject matter, nature, methods, findings, and the future of economics, and to solve the problems regarding these issues and he added that most of the economists were confused and too rigid in their views regarding this issue: 'We want to work out what we should think of today's pure economics, what its nature is, what its methods and findings, and where we should go from here. We want to show its limitations and weaknesses and we want to show to the reader how the latter can be improved. Even in this point people are too rigorous: either one thinks the existing is perfect and does not need any further development or one rejects it totally. Both are equally superficial and convenient. Looking at individual cases, though, we see that neither of these two opinions is totally correct but rather each has elements of the truth.' (Schumpeter 1908/2010, p.xvii)

Schumpeter argues that his own answers, without naming them, are neither based on the Marxist dialectical method nor on the rigid 'apriorism' of the Austrian School in which he was raised, and that some of the methodological views circulating around are merely dogmas. In this sense, he argues that he adopts neither the 'common argumentation, which would not be wrong but would lead nowhere' nor 'the dialectic approach that proves everything and nothing', but he adopts the cognitive theory of economics in the analysis of theories. According to Schumpeter, 'Up to now, every economist has started his 
Yay Turan (2021), Method and scope in Joseph A. Schumpeter's economics: a pluralist perspective, The Journal of Philosophical Economics: Reflections on Economic and Social Issues, XIV (1-2), 63-107

analysis with a priori axioms about the nature of economic activities or human activities and then deduced assertions for this or that method. That cannot lead to any results.' In addition, 'Everything that happens is subject to causality, therefore exact laws have to be possible in the area of economics' does not prove anything either. In that subject, 'what is important is to answer whether the economic connections in real life are as simple as those in the axioms.' (Schumpeter 1908/2010, p. ivx)

On the other hand, regarding one of the important topics of discussion during that period; 'Is the method of economics inductive or deductive?', he correctly states that the economist should use both and that the discussion of this issue is futile. Schumpeter emphasized that economics is methodologically different from physics and biology as well as other social sciences, and he discussed in detail the difference of static-dynamic analysis, the absence of any relationship between methodological individualism and political individualism (Schumpeter 1908/2010, pp.58-61; see also Bögenhold (2018b) for an evaluation of Schumpeter's view on methodological individualism and finally, the necessity of testing each theorem and inference (Schumpeter 1908/2010, p.389)).

We can say that when his work (Schumpeter 1908/2010) is considered as a whole, Schumpeter addressed almost every methodological topic of his time, and in this context, he questioned every methodological proposition very well. He was right in his criticisms in every different singular subject. However, we can also say that he advocated an opposite point of view in a contradictory fashion somewhere else, and therefore he himself fell into the critique of 'being misty and not very clear' about methodological issues which he directed to others. For example, Schumpeter, who criticizes the 'exact' laws or sciences as in the example given in the above paragraph and argues very accurately that the multiple economic links in real life may not be as simple as in the axioms. He also suggests that economics is an 'exact science' that is only at the start of its development period. On the other hand, he emphasizes that the explanations of economics can be defined as a functional or acausal (two-way) relationship rather than a cause-effect relationship like in exact sciences, and that the theorems provide description rather than an explanation (Schumpeter 1908/2010, pp.19, 24, 26, 27 and 29). 
Yay Turan (2021), Method and scope in Joseph A. Schumpeter's economics: a pluralist perspective, The Journal of Philosophical Economics: Reflections on Economic and Social Issues, XIV (1-2), 63-107

However, here we may add that Schumpeter, who defines economics as a science composed of four compartments such as theoretical economics, history of economics, statistics/econometrics, and economic sociology, adopts the approach, which he calls as the Monroe Doctrine (Schumpeter 1908/2010): each of the subfields of economics has its own method; these fields are different and autonomous due to their different subject matters, and it is wrong to extend the method for one field to another.

\section{Schumpeter's understanding of economics}

In our opinion, if Schumpeter's TED is his most important work (Hanusch and Pyka 2007a, p.21; Swedberg 1993, p.21), the seventh chapter issued from the English edition of this work is a good road map or a key for understanding his system of thought. The secret behind the fact that this chapter titled 'Economy as a Whole' has not been translated into English for many years, also directly increased its popularity.

The seventh chapter became the focus of interest above all thanks to the curiosity for the reason why it was removed from the later editions of the book, as well as its requirements as to form: Schumpeter states that he removed the seventh chapter from the English edition because he fears that "the fragment on "Kultursoziologie" in the seventh chapter could sometimes divert the reader's attention from "problems of dry economic theory", which I would like to be solved' (cited by Meerhaeghe 2003, see also Shionoya 1990a). As far as the requirements as to form in the chapter are concerned, it may be seen that the chapter is the longest part of the book. Moreover, there are no sub-headings or divisions in the chapter, and the long (sometimes repeating) paragraphs follow each other, and the chapter ends. For this reason, tracking of the content and the logic sequence of the chapter is challenging for the readers, and the identification of the sub-headings of the section are left to the reader's ability (to make a content analysis of the article) (for such an initiative see Shionoya 1990a, 1997, p.315). So much so that this chapter was stylistically described as 'a compact, shapeless mass of words' (Meerhaeghe 2003, p.240). It may be inferred that Schumpeter also sees these criticisms as justified and explains his self-critique of long paragraphs and sentences with his psychology of 'verbosity 
Yay Turan (2021), Method and scope in Joseph A. Schumpeter's economics: a pluralist perspective, The Journal of Philosophical Economics: Reflections on Economic and Social Issues, XIV (1-2), 63-107

and complacency of youth' (ibid.). There were those who explained this situation with the characteristics of the 1910s (insufficient establishment/ recognition of the concepts of neoclassical economics), as well as with the purpose of Schumpeter for writing this book (for the purpose of clarifying, often without avoiding repetitions, the marginal utility theory of value and Walras's general equilibrium framework to the Society of German Economists who were unaware of these developments and adopted the approach of the German Historical School) (Meerhaeghe 2003).

When we look at the content of the chapter, we see a summary of the basic theses of the book. Schumpeter argues here - going beyond the boundaries of economics - that the theoretical framework he developed can be applied to all social relations in the society, which may be called as the social culture, and may explain the development process of the social culture (which can be called as the cultural change or theory of cultural evolution) (see Schumpeter 1911/2002, p.140): 'We say that each area of social life has its own development and that the mechanism driving these developments is in its fundamental lines everywhere the same. There is only one question left. How is it possible that despite this relative autonomy of each single field there is only one underlying and large truth, a truth, however, which we sense more than that we can actually prove it. This truth is that every element of any area is at any point of time in a relationship with every element of every other area - that all states of all areas mutually determine each other and belong to each other. Let us call the totality of these areas the social culture of a nation and the basic underlying idea of all its developments the social development of culture. Then we can pose the question as to how it can be explained -according to our conception - that the social culture of a nation is at any point in time a unity and that the social development of culture of any nation always shows a uniform tendency?'

Regarding TED, Schumpeter indicates: 'In aim and method, this book is frankly "theoretical" but that "this is no place for a professio fidei (approach) on method' (Schumpeter 1934/1963, p.x). Here, it is clear that Schumpeter was not very willing to join the methodological discussions significantly favoured by the Austrian School where he came from. 
Yay Turan (2021), Method and scope in Joseph A. Schumpeter's economics: a pluralist perspective, The Journal of Philosophical Economics: Reflections on Economic and Social Issues, XIV (1-2), 63-107

When we take into account the whole body of works of Schumpeter, we can say that his basic subject matter or aim (which at the same time defines the fundamental subject matter of economics as a social science or the main job of the economist, he argues) was to develop a theoretical framework to help us conceptualize the state of the capitalist economies we observe in the concrete world at a given point in time, and to explain how and with which economic mechanisms this current economic situation can change (economic evolution or development). However, he also underlines that this is not so easy: The explanation/theory to be developed based on certain concepts shall not sufficiently embrace even solely the economic aspect of the concrete reality, let alone reveal the concrete reality with all its clarity. Being aware of this, the existing (economic) knowledge must be subjected to a critical evaluation, its deficiencies should be determined, and the new theory should be built on it. His view about the process of development of this (economic) knowledge is as follows in his own words (Schumpeter 1934/ 1963, p.x): 'our science cannot, any more than others, dispense with that refined common-sense which we call "theory" and which provides us with the tools for approaching both facts and practical problems. However important may be the bearing of new masses of unanalysed, especially statistical, facts upon our theoretic apparatus - and undoubtedly increasing wealth of factual material must continually suggest new theoretical patterns, and thereby currently and silently improve any existing theoretical structure - at any given stage some theoretical knowledge is a prerequisite to dealing with new facts, that is with facts not already embodied in existing theorems. If this knowledge remains rudimentary and subconscious, it may be bad theory but it will not cease to be theory.'

If we clarify what is said above, we can say that Schumpeter's purpose in TED (1934, p.xi) is to develop an economic theory that embraces singular but interrelated economic phenomena or issues such as credit, capital, interest, business cycles / crises (each of which corresponds to chapters 3 to 6 of TED, respectively) in the flow of economic activities in concrete capitalist societies. This theory requires first to make an assessment (point-time analysis) of the capitalist economic structure in real life, and then to reveal the change/development mechanism/dynamics in this structure (Schumpeter, 
Yay Turan (2021), Method and scope in Joseph A. Schumpeter's economics: a pluralist perspective, The Journal of Philosophical Economics: Reflections on Economic and Social Issues, XIV (1-2), 63-107

1934). Schumpeter calls the necessary approach for the first part as a static analysis and for the second part as a dynamic analysis.

However, developing a theory of economics that will perform the static and dynamic analyses of capitalism is not something to be re-invented from scratch ignoring existing knowledge. Defending the contrary means denying the history of science. Schumpeter also develops his theory in a two-step process: In the first step, by critically evaluating the currently available economic theory, he questions its suitability for purpose. The first part of TED gives us a critical analysis of the General Equilibrium Model, which he calls as a 'circular flow model', to serve this function. The importance of General Equilibrium Model for Schumpeter (or the source of his fascination with Walras's General Equilibrium Model) is that it addresses the simultaneous state of all goods and services in the market(s), in other words, demonstrates the static analysis of capitalism (Schumpeter 1934). In the second step (in the second part of TED), Schumpeter reveals his own approach, questioning what the essence of the general equilibrium model is, as well as the concept of development in classical economics: the dynamic analysis or theory of the economic change/evolution/ development of capitalism.

The methodological framework of this two-step research strategy is described as follows in the beginning of the seventh and final chapter titled 'Economy as a Whole' (See Schumpeter 1911/2002, p.93): 'the underlying idea presented (in first six chapter) forms a unity of method as well as one of substance. It is its purpose to layout a complete conception of a series of closely related economic phenomena. To us this means that there is just one basic line of reasoning, just one way of looking at things, just one and the same group of facts. But it is in the very nature of the problem that with every step on our explanatory journey it is just one particular concrete problem that has figured prominently.'

Schumpeter suggests that the determination and analysis of the situation of an economy at a particular point in time may be reduced to the question of what may be the quantity and prices of goods to be produced within a given economic and social organization within the framework of a geography, population, equipment and needs with the data/specific production methods and stocks of goods? This refers to the problem of equilibrium, with which the economist is not unfamiliar, and he adopts the General Equilibrium Framework, which, as 
Yay Turan (2021), Method and scope in Joseph A. Schumpeter's economics: a pluralist perspective, The Journal of Philosophical Economics: Reflections on Economic and Social Issues, XIV (1-2), 63-107

we mentioned above, he names as the 'circular flows model', for the analysis of equilibrium. He names this analysis, as mentioned above, in his own way: static analysis. Static analysis does not only depict the properties of a specific point in time, but also helps us to conceptualize the analysis of the adaptation mechanism to be demonstrated by economic actors against the change in data conditions (data population, equipment, needs, etc.) mentioned above or against external (governmental) interventions. In other words, static analysis provides a description of the final equilibrium to be re-established, which the economy will regularly reach (Schumpeter 1911/2002). Further, we may add to this process the 'evenly rotating economy' of Schumpeter's classmate Ludwig von Mises (1949/1998, pp.245-251), or the production process named by Karl Marx as the 'simple reproduction model'. Finally, we can analyze two equilibrium states (comparative-static) by using this model. Here, according to Schumpeter, there is no mistake in the General Equilibrium Model. The mistake is to believe that economics consists solely of this subject matter: Economics as the determination of equilibrium (Schumpeter 1911/2002).

The transition from equilibrium to another equilibrium takes us to the concept of economic development, which is the basic subject of the real economics. What needs to be emphasized here is that Schumpeter uses the concept economic development in the meaning of 'economic change'. He argues that the concept of economic development which he uses does not have a positive (progressive) meaning and is perceived as 'neutral': Economic development refers to the deviation from equilibrium and a new (and different from the former) disequilibrium process. Moreover, this concept is neither (evolutionist) biological, nor organic (as Marshall argued), nor is it similar to the mechanical economic development concept of classical economists (best example of which may be seen in J. Clark) (Schumpeter 1911/2002).

When we examine the economic phenomena in the concrete world within this theoretical framework, we come across two issues. First is a problem of economic history and economic geography in its one aspect when we consider the development of economic events in an individual capitalist country: While some sectors are emerging and rising within the framework of a specific industrial organization, production methods, quantities, technology, demand etc., why are others recessing or pulling out of the market? According to 
Yay Turan (2021), Method and scope in Joseph A. Schumpeter's economics: a pluralist perspective, The Journal of Philosophical Economics: Reflections on Economic and Social Issues, XIV (1-2), 63-107

Schumpeter, the answer to this question is that the description of the concrete course of economic development covers the issue of how and under what conditions economic development occurs, which is the job of economic history/economic historian (Schumpeter, 1911/2002).

However, a second question may be asked about the phenomenon of economic development in the concrete world: When a new economic development occurs, does the order and the mechanism of change show a regularity/similarity/ identicalness (with the previous one)? If so, can we reach a generalization or formulation based on observation of individual samples? Or can we get a 'general picture' of economic development even if it is rough? Even if economic historians or some economists (such as the members of the German Historical School) may respond positively to this question, this answer/explanation will 'not be theoretical but historical/descriptive' (Schumpeter 1911/2002, p.95). In other words, comprehensive studies, as an observed stock of knowledge, which is obtained using the method of inductive logic only, cannot be accepted as theory, but can only be quasi-theory formations according to Schumpeter.

The job of the theoretical economist is to develop a general framework (ideal type) that would explain the mechanism of development (change) of the economic phenomenon which he/she deals with at a certain level of abstraction based on the special features or variables deemed important in economic life. However, this framework/explanation will be a 'scheme that often suits the economic development phenomena' rather than revealing a 'cause-effect relationship' (Schumpeter 1911/2002, p.96). Discussion for using both deductive and inductive methods in the development of this general framework is meaningless. For this purpose, Schumpeter begins with a critical assessment of the classical economic development theory of the time, and of John Bates Clark (1915/2007), which he considers as its 'open and systematic exhibition' (Schumpeter 1911/2002, p. 99).

Schumpeter states first that the classical theory is not completely incompatible with his own theory. According to him, the theory of classical development explains development with changes in the environment and the economic elements of the environment. These elements of environmental change are grouped under five headings: an increase in the population, a change in consumer preferences, an increase in the amount of capital, improvement in 
Yay Turan (2021), Method and scope in Joseph A. Schumpeter's economics: a pluralist perspective, The Journal of Philosophical Economics: Reflections on Economic and Social Issues, XIV (1-2), 63-107

the production methods and improvement in the industrial organization of the industrial society. According to Schumpeter, there is no problem about people who are arguing that these variables can change the economic structure of the economy; he agrees with them. In his opinion, the problem relates to the mechanism or mode of influence of these variables on the economic structure: in the theory of classical development (J.B. Clark), the phenomenon of economic change or development is dealt with by the logic of static analysis, and the influence is claimed to be specific single type (in the form of tending towards equilibrium). However, according to Schumpeter (1911/2002, p.108): 'Development, in its deepest character, constitutes a disturbance of the existing static equilibrium and shows no tendency at all to strive again for that or any other state of equilibrium. Development alters the data of the static economy. This does not occur by organic reconfiguration, but in particular through the new creations - as it were, non-organically. Development has a tendency to move out of equilibrium. (...) Thus, development and equilibrium in the sense that we have given these terms are therefore opposites, the one excludes the other. Neither is the static economy being characterized by a static equilibrium, nor is the dynamic economy characterized by a dynamic equilibrium.'

The common denominator of these two theories (Walrasian General Equilibrium Theory and Clark's Theory of Economic Development / Theory of the Dynamics of Capitalism) is that they resemble the laws of mechanics: In mechanics, unless an external force acts on a static mass, the mass remains unchanged, and a new mechanical phenomenon cannot be generated. If an external force acts on this mass, the response of the mass will be a change in the form of adaptation to the specific type, automatic external effect. Similarly, in the 'circular flow model', the equilibrium will remain unchanged unless there is an external effect. However, the effect of a change in one of the abovementioned environmental factors on the system (or the behaviour of economic agents) would likewise be the adaptation to the external effect, and the behaviour of automatically tending again towards the (same) equilibrium. In short, the theory of the classical development / dynamics of capitalism excludes the phenomenon of a development that comes from within the economy itself (purely economic). In other words: 'And yet the theory is empty. It says nothing insofar as it is correct and insofar as it says anything at all it is wrong. In its 
Yay Turan (2021), Method and scope in Joseph A. Schumpeter's economics: a pluralist perspective, The Journal of Philosophical Economics: Reflections on Economic and Social Issues, XIV (1-2), 63-107

essential or universal form, foreign forces determine the life of nations and of the economy including natural forces of all kinds. (...) this conception asserts that the economy as such is nothing but pure result, that its role is only passive, that it is merely being propelled and that it is not a propelling force by itself, that it is the other [non-economic] forces that a reactive and that the entire course of economic events is only to be understood as a reflection of their effects.' (Schumpeter 1911/2002, p.98)

However, although the theory of purely economic development does not deny that external/non-economic variables may have an impact on the structure/change of the economy, they explain the change in the basic structure of the economy (in the level of equilibrium in the circular flow model) with the activities of entrepreneurs where they carry out 'new combinations' intrinsic to purely economic relations. We see that the 'new combinations' of these entrepreneurs are further elaborated in Schumpeter (1934/1963, p.66):

- Offering a new commodity or good which is not known by the consumers, or which is at a different quality,

- Developing a new production method that will provide a commercially different presentation of the goods (which are not necessarily based on a new scientific discovery) and which have not been tried in the relevant sector,

- Opening a new market;

- Finding a new raw material or intermediate;

- Occurrence of organizational changes such as the emergence or elimination of a new monopoly in a sector.

Economic development can be summarized by three basic principles: economic development is a purely economic phenomenon, economic development refers to a deviation from equilibrium and economic development is not an organic phenomenon that forms a whole, but rather consists of consecutive (relatively separate) partial developments. As a fourth element, we can add that the economic development exhibits a wave-like appearance in the concrete world. However, what is important here is that economic development consists of individual minor developments that occur at the same time/follow each other, 
Yay Turan (2021), Method and scope in Joseph A. Schumpeter's economics: a pluralist perspective, The Journal of Philosophical Economics: Reflections on Economic and Social Issues, XIV (1-2), 63-107

rather than a single, an integrated line of development. As economists, although we cannot speak of a general economic development, we can reveal the shared mechanisms of partial developments (Schumpeter 1911/2002, p.108). Schumpeter gives an important example of the fact that he adopted the methodological individualism approach by underlining that the real-world economic development and the objectives of the economic agents of this process must not be considered as an aggregate economic development embodied in an organic entity. He expresses economic development as follows: 'This [up and downward secular movements] is the formal nature of the process which periodically revolutionizes and reorganizes industrial life. It has an effect on all areas, creates new forms of life everywhere. Its most inner meaning lies in the procurement of new kinds of goods and quantities of goods and in the reorganization of the economy towards more technical and commercial effectiveness.' (Schumpeter 1911/2002, pp.109-110)

The impact of development on economic agents has two aspects. On the one hand, the existing demands are met through the reorganization of the economy as well as the new production processes; on the other hand, the entrepreneur has its own monopolistic power to create completely new goods/demands, and this is where profitability comes to the fore. Gains and losses occur at the same time in the economic development process, but they affect different economic agents. However, the first impact of development is the increase in the profit of the entrepreneur and the capitalist. In this sense, profit is the force that drives the process. Besides, this increase in wealth is not continuous; the activities of other entrepreneurs cause their profits to fall. This development process affects/increases the income of the workers and landowners as well as the profits of the entrepreneurs. The expansion phase of economic development is accompanied by price increases, nominal prices are increased. Moreover, the production of existing goods by using new technologies and the production of new goods lead to price decreases in favour of workers and landowners. In short, a new form of production or organization or technological change created by the entrepreneur creates welfare increases for some economic actors in the expansion and recession stages of the business cycles, while it leads to losses (even bankruptcies) for some economic agents (Schumpeter 1911/2002). 
Yay Turan (2021), Method and scope in Joseph A. Schumpeter's economics: a pluralist perspective, The Journal of Philosophical Economics: Reflections on Economic and Social Issues, XIV (1-2), 63-107

We can group our assessment of the economic development process of Schumpeter, which we show here, under three points: The first is about the way the text is expressed. The process of economic development was written in a very unclear or frankly complex manner (perhaps enough to discourage the reader who reads it for the first time from reading). Second, the process presented here is the (yet) unnamed display of the concept of 'creative destruction', which Schumpeter reveals in CSD (Schumpeter 1943/2003) and has become as popular as his name. The third (and the most important) is the inference of the model regarding unemployment. There is no room for continuous unemployment and unemployment that applies to the whole economy in the model; when there is a continuous and general unemployment in an economy, it is necessary to consider the special conditions of that country (of the time and place) [2]. This issue refers to a significant difference that Schumpeter (also Friedrich August von Hayek (1933)) disagreed with Keynes where Keynes was right in his explanation of the concrete world in his General Theory (1936): as may be seen in the Great Depression of 1929, there may be general and long-term unemployment in the whole economy in capitalism.

Schumpeter argues that in the capitalist economic order, 'the economic system' which consists of the totality of economic relations, mutually interacts with the values system, which is a combination of the social systems and the individual values, and his own economic analysis may be used in understanding the developments in the social and the values system of this capitalist system (Schumpeter 1928; 1934/1963). Three points must be underlined within this context:

- The presence of two different problems and two different methods for their analysis. First is the situation assessment (point-time analysis) in each area of human life, determining which structure is challenged by the environmental conditions (static analysis). Second is the revelation of the development mechanism in this area (dynamic analysis). Both problems correspond to a group of different events and the understanding of what is happening in the concrete world requires different forms of analysis.

- Using two different types of people or behaviour for the solution of these two basic problems. In each area of social life (such as politics, art, science), there are people who tend to act within the framework of status 
Yay Turan (2021), Method and scope in Joseph A. Schumpeter's economics: a pluralist perspective, The Journal of Philosophical Economics: Reflections on Economic and Social Issues, XIV (1-2), 63-107

quo as well as there are people who tend to change the status quo/existing rules. Schumpeter argues that the energetic people with innovative and leadership qualities, whom he regards as the dynamic engine of the economic development process, are the main driving force of change in also other areas of human life (such as politics, art, science) with their energetic and innovative behaviour.

- Each (economic, sociological, political, scientific, or artistic) aspect of human life continues to develop in a mutual interaction while simultaneously maintaining their own autonomous flow. Together they all refer to social reality (social culture in Schumpeter's terms) and its evolution. Therefore, there may be an 'explanation in the form of a functional relationship' for social reality which refers to a mutual interaction, rather than an explanation in which one aspect of social life determines other aspects of social life, in other words in the form of 'causeeffect'.

Thought provoking inferences may be made about this third point: First, it seems that Schumpeter tried to do the 'Grand Science Project' which the Vienna Circle was trying to do in the 1920s in the context of social sciences: 'universal social science' (Weintraub 2002). The interesting point here is that the concept of (calculable) mutual equilibrium of a large number of markets at a given point in time (point time), which is suitable for static analysis, is transformed into a functional relationship that also reflects the simultaneous mutual interaction of various (economic, social, cultural) aspects of human behaviour: a common equilibrium (coordination) problem between the various aspects of human behaviour.

This point also highlights two relationships that Schumpeter sees as Karl Marx's important contributions to economic analysis: Marx established an exceptionally good organic combination of economic theory and economic sociology in explaining the social/cultural structure of capitalism. In other words, using the Theory of Social Classes and the Economic Interpretation of History, he integrated very well 'the connection between conditions of production and social organization' (Schumpeter 1912/1954, p.12; Schumpeter 1943/2003, p.20): 'Marx defines capitalism sociologically, i.e., by the institution of private control over means of production, the mechanics of capitalist society 
Yay Turan (2021), Method and scope in Joseph A. Schumpeter's economics: a pluralist perspective, The Journal of Philosophical Economics: Reflections on Economic and Social Issues, XIV (1-2), 63-107

are provided by his economic theory. This economic theory is to show how the sociological data embodied in such conceptions as class, class interest, class behavior, exchange between classes, work out through the medium of economic values, profits, wages, investment, et cetera, and how they generate precisely the economic process that will eventually break its own institutional framework and at the same time create the conditions for the emergence of another social world. This particular theory of social classes is the analytic tool which, by linking the economic interpretation of history with the concepts of the profit economy, marshals all social facts, makes all phenomena confocal.'

The second relationship, which is important for the methodology of economics, emphasizes the relationship between economic theory and economic history (Schumpeter 1943/2003, p.44): 'Economists always have either themselves done work in economic history or else used the historical work of others. But the facts of economic history were assigned to a separate compartment. They entered theory, if at all, merely in the role of illustrations, or possibly of verifications of results. They mixed with it only mechanically. Now Marx's mixture is a chemical one; that is to say, he introduced them into the very argument that produces the results. He was the first economist of top rank to see and to teach systematically how economic theory may be turned into historical analysis and how the historic narrative may be turned into historic raisonnée.'

\section{Economics and the development of economics in the context of sociology of science}

In Schumpeter's book on the history of economic thought which he authored in the last stage of his life (Schumpeter 1954/1986) he describes the history of economic analysis as 'the history of the intellectual efforts that men have made to understand economic phenomena' or 'the history of the analytic or scientific aspects of economic thought'. In this sense, the history of economic analysis helps us to understand the current state of economics as well as its development trend over time (Schumpeter 1954/1986, p.3): ‘(Although today's knowledge includes knowledge of the past) Scientific analysis is not simply a logically consistent process that starts with some primitive notions and then 
Yay Turan (2021), Method and scope in Joseph A. Schumpeter's economics: a pluralist perspective, The Journal of Philosophical Economics: Reflections on Economic and Social Issues, XIV (1-2), 63-107

adds to the stock in a straight-line fashion. It is not simply progressive discovery of an objective reality - as is, for example, discovery in the basin of the Congo. Rather it is an incessant struggle with creations of our own and our predecessors' minds and it "progresses," if at all, in a criss-cross fashion, not as logic, but as the impact of new ideas or observations or needs, and also as the bents and temperaments of new men, dictate. Therefore, any treatise that attempts to render "the present state of science" really renders methods, problems, and results that are historically conditioned and are meaningful only with reference to the historical background from which they spring.'

According to Schumpeter, the development of economics is not different from the development of other sciences, although there is a historical process composed of different periods dealing with different events and problems (in other words, the process of producing, developing, and destroying economic structures of man to understand the economic phenomenon) (Schumpeter 1954/1986).

The second important issue in this book by Schumpeter is what kind of a science economics is and its relation to other sciences. According to him, exact sciences come to mind when one speaks of science, and the best example of this is 'mathematical physics'. Neither social sciences nor economics is a science in this sense. When we consider science from the point of view of its one of the most important characteristics i.e., 'science is measurement', some part of economics is considered science and some of it is not considered science (Schumpeter 1954/1986).

Schumpeter approaches the concept of science not from the point of view of the object of science (knowledge), but from the point of view of its subject (scientist's activity of producing scientific knowledge). In this sense, it also appears to be a pioneer of the sociology of science approach which would also dominate economics from the late 1960s onwards (via physical sciences): According to him, 'science is any kind of knowledge that has been the object of conscious efforts to improve it.' These efforts help us produce various methods and techniques while controlling the events that we can discover using these techniques which have been developed beyond the knowledge and thought habits of everyday events. This practically means 'a science is any field of 
Yay Turan (2021), Method and scope in Joseph A. Schumpeter's economics: a pluralist perspective, The Journal of Philosophical Economics: Reflections on Economic and Social Issues, XIV (1-2), 63-107

knowledge that has developed specialized techniques of fact-finding and of interpretation or inference (analysis)' (Schumpeter 1954/1986, p.6).

Within the concept of the sociology of science, 'a science is any field of knowledge in which there are people, so-called research workers or scientists or scholars, who engage in the task of improving upon the existing stock of facts and methods and who, in the process of doing so, acquire a command of both that differentiates them from the "layman" and eventually also from the mere "practitioner." In short, Science is 'refined common sense' or 'tooled knowledge.' In this sense, 'since economics uses techniques that are not in use among the general public, and since there are economists to cultivate them, economics is obviously a science within our meaning of the term.' (Schumpeter 1954/1986, p.6). However, according to Schumpeter, the point to note here is that although science is defined as, 'tooled-knowledge' (information produced with the help of developed techniques), there is no general rule with which we will decide which knowledge produced by which techniques is scientific (astronomy) and which are not scientific (astrology). In this regard, the concepts of 'modern', 'empirical' or 'positive science' (in a sense limiting the scope of science) may help us: although there is no general rule, we are talking about a field which uses techniques where we can make logical inferences from verifiable events whose object is a set of events which are verifiable by observation or experiment. As we may not speak of the absolute validity of the inferences obtained in this context, it does not mean that these propositions are non-scientific just because we claim that they are not valid according to our conventions/criteria. In addition, 'to define science as tooled knowledge and to associate it with particular groups of men is almost the same thing as emphasizing the obvious importance of specialization of which the individual sciences are the (relatively late) result' and it is necessary to highlight here that science cannot be confined to a defined subject or method and that these may always change. Thirdly, what matters about scientific knowledge is not who said it or how, but rather whether it is true or not.

Schumpeter lists economic analysis techniques that should be included in the economist's bag as history of economics, statistics, economic theory, and sociology of economics. The first and the foremost among these, history of economics, helps us understand today's economic phenomena with the help of 
Yay Turan (2021), Method and scope in Joseph A. Schumpeter's economics: a pluralist perspective, The Journal of Philosophical Economics: Reflections on Economic and Social Issues, XIV (1-2), 63-107

events, techniques and information related to previous years which it provides. Since the information of the past includes not purely economic but also institutional events, it renders the difference between economic and noneconomic knowledge and thus the relationship between economics and other social sciences important (Schumpeter 1954/1986, p.11). The second technique, statistics, allows us to explain things and even to determine what we need to explain. In addition, it requires being aware of the techniques by which we will make inferences from these and also their epistemology. Knowing modern statistical methods is one of the necessary conditions (although not sufficient) to prevent the economist from producing meaningless results (Schumpeter 1954/1986, p.12 and Schumpeter 1939). The third technique is the field of economic theory. According to Schumpeter, although the theory may be called 'explanatory hypotheses', the function of economic theory is not much different from the function of theoretical physics: it is to develop schemes or models that enable us to address and examine certain aspects of reality and to draw some inferences starting from these by using certain methods. The things (propositions) we take here (as given) are called hypotheses, axioms, postulates, assumptions, or principles, while the things we develop/build by certain methods (propositions) are theorems. Because the hypotheses are based on the observation of the observer of reality, they are logically what the researcher has created (intellectual product) although they are about events. In this context, the explanatory hypotheses, in a sense, refer to instruments or tools that will be used to show interesting elements to address the subject that is being investigate', and in another sense, they are about the 'results desired to be achieved, which are actually investigated in the research'. In short, Schumpeter describes the economic theory as the combination of concepts developed based on hypotheses, the relations between these concepts and the methods required for their analysis or (by using John Robinson's concept) as a 'box of tools' (Schumpeter 1954/1986, p.13).

This finding of economic theory applies to other sciences as well: an event of a particular class of phenomena is seen as an individual (exemplary) event in the real world. Events of the same group are similar. By observing and then conceptualizing these individual events, a formal structure, a bundle of tools, a structure that we will use, no matter what the problem is, is created. Here two 
Yay Turan (2021), Method and scope in Joseph A. Schumpeter's economics: a pluralist perspective, The Journal of Philosophical Economics: Reflections on Economic and Social Issues, XIV (1-2), 63-107

points are underlined that distinguish the theory of economics (from physical sciences): economists do not have a laboratory (like physicists); however, there is the superiority of the observation of human behaviour and the understanding (verstehen) of making insightful-observational inferences. We also see the distinction between formal-normative propositions/sciences (theorems about logic, ideals, or norms), real-positive propositions/sciences (theories aiming to show causality among some variables in the concrete world using observations) in Schumpeter although they are not named as such. In this context, Schumpeter deems Hayek's critique of using methods of physical sciences in the social/economic sciences without questioning (scientism) as important, although he does not mind using the mathematical techniques, which are 'a common language' for economists (Schumpeter 1954/1986, pp.14-15).

Schumpeter points out to the economic sociology as the fourth technique that an economist must have, in other words, the importance of the institutional environment in economic analysis (Schumpeter 1954/1986, p.19): 'Economic analysis deals with the questions how people behave at any time and what the economic effects are they produce by so behaving; economic sociology deals with the question how they came to behave as they do. If we define human behavior widely enough so that it includes not only actions and motives and propensities but also the social institutions that are relevant to economic behavior such as government, property inheritance, contract, and so on, that phrase really tells us all we need.'

Schumpeter also discusses the relationship between ideology and economics as a science, as well as the development/evolution of economics based on the philosophy of science and the sociology of science. In this context, he discusses the question of whether the history of economic analysis is the history of ideologies: According to Schumpeter, the historical and evolutionary nature of the economic process limits the concepts and relations within the scope of analysis of the economists. Sometimes it is said that the concepts and relationships related to concrete life cannot be formulated, but the concepts and relationships we theoretically use do not necessarily correspond exactly to those in the concrete world. Secondly, the laws of economics are not as stable as the laws of physics; they may give different results in different institutional environments. On the other hand, the researcher may accept 'the behaviour 
Yay Turan (2021), Method and scope in Joseph A. Schumpeter's economics: a pluralist perspective, The Journal of Philosophical Economics: Reflections on Economic and Social Issues, XIV (1-2), 63-107

and thought patterns of those observed' at different times and places as the same with their own thoughts and ideological biases. In this context, Schumpeter emphasizes that the role of ideological bias is important in economic analysis and highlights the concept of 'ideological biases' that Marxists focus on in their critique of 'the bourgeois economics'. According to Marxists, thoughts, or systems of thought of man are not the key driving forces of the historical process, they are actually elements that form the superstructure. The ideologies as 'systems of thought' reflect the ideology of the commercial and industrial bourgeoisie. Schumpeter criticizes this approach in three aspects. First, although Marx calls different systems of thought as ideologies, he does not include his own system of thought in that. Secondly, while 'a system of thought' is defined as an ideology, it is defined only by the interests of the group and therefore by the economic elements, whereas ideology is something beyond an economic concept. Thirdly, although the propositions may have been influenced by ideologies, what matters is whether the propositions are true or not. It is therefore important to answer the question of whether the propositions can be distinguished from ideologies and whether 'a scientific truth' independent of ideologies is possible (Schumpeter 1954/1986, pp. 33-35).

In this context, Schumpeter discusses the extent to which ideological judgments can influence the processes and results of economic analysis (Schumpeter 1954/1986, pp. 38-45). According to the author, the process of production of economic knowledge (economic analysis) may be divided into two parts, vision and analysis. He calls the first phase of the analytical study as the 'preanalytic cognitive act' which refers to 'initial or raw materials'. The second stage, analysis / analytical effort, is the process of converting the raw information expressed by words in the vision into a conceptual scheme or photograph that contains certain elements. Throughout this process, while some of the initial phenomena are excluded from the analysis, some new concepts are added, or changes may be made in some concepts and relationships. The mutual interaction between the raw information gathered and the theoretical work on these phenomena corresponds to the process of developing a 'scientific model', during which thoughts are developed with the visionary raw information as well as several standards such as 'consistency' 
Yay Turan (2021), Method and scope in Joseph A. Schumpeter's economics: a pluralist perspective, The Journal of Philosophical Economics: Reflections on Economic and Social Issues, XIV (1-2), 63-107

and 'adequacy'. Since analytical work begins with vision, there may be ideological biases there. Since analytical work starts with our vision (preanalysis cognitive behaviour), it may be possible to confuse what is observed with what is desired to be seen in the inferences that are made. However, in the analysis stage, as well as there may be phenomena that are not affected by ideology, some processes or techniques used in the analytical work are not much affected by emotions and also may prove certain things to be wrong and lead to the elimination of ideological deception (Schumpeter 1954/1986, p.44).

The second phase of the analytical study, analysis, also consists of two parts. The first is clarifying the definitions to conceptualize the contents of the vision, clarify various names or concepts and establish the connections between them. The second is the process of developing the analytic work (in terms of content and scope) in the light of new facts / empirical data in this conceptual process. Throughout this process, developing, correcting, and deepening the original vision and its consequences will require the use or development of diagrams, systems or models that will best describe the subject dealt with in addition to the deductive and inductive methods at any stage of the research process (Schumpeter 1954/1986, p.43).

Schumpeter underlines two additional points related to this process. First, the inferences/conclusions obtained by analytical work are always temporary propositions developed within the framework of the available facts/data. Second, there is no contradiction between theory and a new fact-finding. If scientific conclusions are functioning/working and are useful, it is possible to develop new techniques and methods and apply them to new fields. This indicates the sociological aspect of economics as a science: most scientists teach, develop, and pass on to future generations these available knowledge, techniques, and methods. In this process, (as a labour-saving social mechanism) new masters (generation of scientists) who dominate the existing theoretical framework are raised on the one hand, and on the other hand, the difficulties/obstructions of the current theoretical framework may lead to the development of new perspectives and/or new methods, and to the emergence of a 'revolutionary development'. In other words, scientific development or revolution may not only be due to changes in the environmental conditions and 
Yay Turan (2021), Method and scope in Joseph A. Schumpeter's economics: a pluralist perspective, The Journal of Philosophical Economics: Reflections on Economic and Social Issues, XIV (1-2), 63-107

data, but also because existing knowledge and techniques cannot explain new developments (see also Kesting, 2006).

To summarize, the originality and interestingness of these views of Schumpeter about the nature and development process of science or economics as a social science are that they were raised before the experiences of the economists of the period from the 1970s to 1990s who viewed economics from the perspective of the philosophers of science such as Karl Popper, Thomas Kuhn and Imre Lakatos (for comparison of Schumpeter with Thomas Kuhn and related literature in methodology of economics see, Backhouse 1996, Kesting 2005). Finally, it is worth noting an interesting issue in the part of the chapter which focuses on the relationship between economics and philosophy. Schumpeter states that philosophy referred to 'the whole knowledge and the entire set of analytical tools and events that cover everything from metaphysics to physics, from mathematics to logic, from society to state philosophy' until the mid-18th century and that in a sense it corresponds to universal science. He adds (Schumpeter 1954/1986, p.27): 'When we look over those comprehensive systems of science, we cannot fail to make a discovery of the utmost importance for the problem. Neither Aristotle nor any of the later polyhistors succeeded in unifying, or even attempted to unify, the various departments of his teaching and, in particular, to assert in each of them his views on the "last causes," the "ultimate meaning" of things, and the like. Therefore, we had better speak of a compound of sciences rather than a universal science.'

In a nutshell, according to Schumpeter, just being an economist is not enough for an economist. His/her subject matter, human actions and relations, is a multi-dimensional phenomenon. In today's world where every discipline is extremely specialized, even if the gains from collaboration (trade) are not certain, the door of economics to sister sciences should be kept wide open. What Schumpeter wants to say here, interestingly, corresponds to an argument regarding the pluralist approach today: 'Assuming, then, that specialization is a fundamental human process, a pluralist response based on the idea that the world is a complex system seems the best response. Specialization does not make the fragmentation of human activity inevitable, but it does make it possible, leaving what will actually occur a matter of how it is addressed.' (Davis 2019) 
Yay Turan (2021), Method and scope in Joseph A. Schumpeter's economics: a pluralist perspective, The Journal of Philosophical Economics: Reflections on Economic and Social Issues, XIV (1-2), 63-107

\section{Conclusion}

Throughout his academic career, Schumpeter adopted to develop a theoretical framework for the internal analysis of the capitalist economy's change/evolution process (based on purely economic factors) as the primary subject matter. For this purpose, he evaluated existing theories (especially those of Austrian (Wieser) and Walras) (Schumpeter 1908/2010) and decided that Walrasian general equilibrium analysis was adequate for point-time analysis of the capitalist economy (Schumpeter 1934/1963, Chapter 1). However, Schumpeter was convinced that Walrasian General Equilibrium Theory was not appropriate for the dynamic analysis of the change process of the capitalist system. He therefore developed his own dynamic analysis of the evolutionary process of capitalism. In the first version of this analysis (Schumpeter Mark I), he introduced a model for the process of capitalist economic development/change based on the innovative activities of the entrepreneur (Schumpeter 1934/1963, Chapter 2-6), and then extended his analysis to both short and long-term analyses of business cycles (Schumpeter 1939). In all these works, Schumpeter assumed that the institutional structure had not changed since the 19th century. But in CSD, Schumpeter developed his second model of the evolutionary process of capitalism based on the fact that the institutional structure changes over time. This model (which is called as Schumpeter Mark II) emphasizes that the fundamental driving force of the change in capitalism is the technological innovations of large firms in imperfect competitive markets.

We may also mention three stages regarding Schumpeter's view on the discipline of economics in the context of the philosophy of science. In his first book on methodological discussions in economics, Schumpeter (1908/2010) argued that the studies of economic theory and the studies of economic history must be addressed as two separate fields in economics (not to be confused with one another) (he called this separation as the Monroe Doctrine). In his second book (1912/1932), he tried to combine the approaches of understanding and explaining on the one hand, and on the other hand, he tried to develop a framework of economics with a broad perspective (economy as a whole/universal economics or social science). In his latter books (1943/2003, 1954/2006), he embraced a kind of methodological pluralism, not in the sense of 
Yay Turan (2021), Method and scope in Joseph A. Schumpeter's economics: a pluralist perspective, The Journal of Philosophical Economics: Reflections on Economic and Social Issues, XIV (1-2), 63-107

using multiple criteria to choose the correct/scientific theory, but in the sense of adopting theoretical, statistical, historical, or sociological techniques accordance with the subject at hand.

When we evaluate Schumpeter's views as a whole, we can say that they correspond to three recent debates in the economic methodology, and in this sense, they are up to date. First, when we look at the pluralism debates in economics since the 1970s (Maki 1997 and 2009, Kellerts, Longino and Waters 2006, Garnett, Olsen and Starr 2010, Davis 2014, 2016 and 2019, Dutt 2014) we can say that Schumpeter is 'a second wave pluralist'. He argued that there are different methods and different approaches in economics, and they can be used according to the topic discussed. Social phenomena in the concrete world are too complex and rich to be grasped by a single method, approach, or discipline. Rather than monistic and polarized approaches as seen in the firstwave pluralism debate during the 1970s and 1980s, he clearly adopts a more liberal and more tolerant approach, and openness to contrast ideas in the discussions between economists. [3]

Second, the ongoing debate between economists and economic methodologists on the interactions between economics and other disciplines (with the titles like 'interdisciplinarity-multidisciplinarity', 'economics imperialism-reverse imperialism' or 'insulation-social scienciation') [4] is the main subject matter that was on Schumpeter's agenda throughout his academic life. What is surprising is that no reference is made to Schumpeter's works in the relevant studies (with the exception of Bogenhold 2017 and 2018a). What we want to emphasize here is that, aside from the obstinate formalist neoclassical economists [5], although a significant part of economists who write on pluralism in the 21st century suggest communication and critical discussion between schools in economics and social sciences, Schumpeter has always been tolerant and open to different approaches in all his works. From his habilitation study to the HOEA, he represented a pluralist perspective trying to establish a connection between different approaches (from German Historical School to Walras's general equilibrium theory, from Karl Marx' ideas to the Austrian School). In addition, he was also a leading pluralist of the first half of the twentieth century who internalized pluralism in his whole personal academic life. For example, he was intellectually open enough to befriend 
Yay Turan (2021), Method and scope in Joseph A. Schumpeter's economics: a pluralist perspective, The Journal of Philosophical Economics: Reflections on Economic and Social Issues, XIV (1-2), 63-107

simultaneously Ludwig von Mises, Otto Bauer and Rudolf Hilferding, who were from opposing political views. Similarly, he was open to mentoring assistants/students who adopted a variety of opposing perspectives in their later academic lives (e.g., James Tobin, Paul A. Samuelson, Nicholas Georgescu-Roegen, Paul Sweezy and Hyman Minsky).

Third, Schumpeter argued an evolutionist or sociological approach to the development of economic thought. Economics as a social science, despite building on its previous knowledge, indicates a zigzagged and revolutionary development line in the face of problems. In this context, while he has a similar view with Thomas Kuhn in terms of defining a conceptual framework (value judgments-paradigm/vision-analysis), his view that new approaches can be built on previous approaches differs from Kuhn's 'incommensurability' thesis and the idea that a new approach will be developed from completely different foundations. [6]

Beside his methodological views, Schumpeter also continues to be on the agenda of economists with his ideas on economic theories and policies. Some of them are discussions on credit-money, venture capital, entrepreneurial competition process, dynamic analysis of the innovation and evolution of industries, theory of economic growth and international trade based on technological innovation, and economic policies (for some studies on these discussions, see Peneder and Resch 2021, Hanusch and Pyka 2007b, Legrand and Hagemann 2017, Malerba 2005, Festré, Lakomski-Laguerre and Longuet 2017, Arena and Dutraive 2016, Malerba and McKelvey 2020).

\section{Endnotes}

[1] Undoubtedly in the 20th century, Schumpeter is the most well-known name of entrepreneur theory and the economist who most influenced the literature on entrepreneurship in economics. However, the various theories have been suggested both in his time (e.g., by Mises, Hilferding), and previously (e.g., by Cantillon, Say, Mill) and in later times (e.g. by Knight, Kirzner, Hirscman, Baumol) (see, respectively, McCaffrey 2013, Hebert and Link 2006, Knight 1921/1964, Mises 1949/1998, Kirzner 1997 and 1999, Baumol 1968, 1990). In a 
Yay Turan (2021), Method and scope in Joseph A. Schumpeter's economics: a pluralist perspective, The Journal of Philosophical Economics: Reflections on Economic and Social Issues, XIV (1-2), 63-107

nutshell, although more than ten characteristics of the entrepreneur are mentioned in these theories, the most important ones are leadership, innovator, risk-taker, capital-owner, and manager. Schumpeter especially emphasized the first two. (On the evolution of the concept of entrepreneur(ship) in Schumpeter's studies see. Becker and Knudsen 2003, and Schumpeter 2003.) In recent times, we can say that there are relatively recent and rapidly growing studies concerning entrepreneurship that can be recognized as a separate, multi-disciplined research field. Entrepreneurship has been developed in several disciplines including economics, management, sociology, psychology, anthropology, finance, and geography, and representing a variety of research traditions, perspectives, and methods. The common view of the social scientists who study entrepreneurship is that, although it is a growing subfield within several disciplines, there is not a generally accepted common theoretical framework or central research paradigm on entrepreneurship (Carlson et.al. 2013).

[2] 'The phenomenon of unemployment with the means of pure theory, i.e., from the essence of the economic mechanism, cannot be explained without an unexplained remainder. (...) That cause of permanent - and ever worsening unemployment simply does not exist as such and only forms the basis of temporary unemployment. (...) Therefore, we can only explain transitory unemployment - and mainly as a frictional phenomenon - but not other kinds of unemployment. This result is not sufficient, but it is not without value. It doubtlessly explains a good deal of the phenomenon of unemployment, in my opinion its better half. But also, its negative meaning should be noticed. One can rather conclude from the fact that unemployment cannot be completely explained by theory that as far as it remains unexplained it rests on other causes than those which lie in the essence of the economic process. If we wanted to investigate the problem of unemployment, then we would now look for other causes directly in the given data of facts. We would not expect to find a comprehensive phenomenon that explains it all, but we would expect to find a lot of different explanations, which would vary with respect to location and time.' (Schumpeter 1911/2002, pp.119-120). This quote raises the question: Could one of the reasons behind Schumpeter's removal of the chapter 7 from 
Yay Turan (2021), Method and scope in Joseph A. Schumpeter's economics: a pluralist perspective, The Journal of Philosophical Economics: Reflections on Economic and Social Issues, XIV (1-2), 63-107

the English edition of TED be this inference of his theory (during the years of the Great Depression) about unemployment?

[3] The difference between first wave pluralism and second wave pluralism is a transformation process from 'a polarized, rigidly segmented discipline' (Davis 2014) (or from a 'fight science with science' strategy) (Garnett, Olsen and Starr 2010, p.2) to a social science 'involving critical conversation and tolerant communication between different approaches' (Sent 2006, Marqués and Weisman, 2010).

[4] For this debate, see Lazear 2000, Maki 2009, Dow 2008, Cedrini and Fiori 2016, Davis 2006, 2016 and 2019, Marchionatti and Cedrini 2017, Bogenhold 2017 and 2018a.

[5] Here, it is interesting that a distinguished formalist economist, Frank Hahn, who defends 'the necessity of preventing the discussion of mathematics in economics like the "plague" and the unnecessariness of methodological discussions' (Backhouse 2010), uses the following two statements one after the other in the same paragraph: 'It is that neither is there a single best way for understanding in economics nor is it possible to hold any conclusions, other than purely logical deductions, with certainty. I have since my earliest days in the subject been astonished that this view is not widely shared. ... For it is obvious to me that we do not possess much certain knowledge about the economic world and that our best chance of gaining more is to try in all sorts of directions and by all sorts of means.' (Hahn 1984, pp.7-8). Schumpeter's difference from Hahn was that he defends the second part of the quotation, arguing that mathematics is an important (but not only) tool for economics.

[6] Since our study is long enough, we do not want to elaborate on the relations between Schumpeter's ideas and Imre Lakatos's and Thomas Kuhn's views (see Drakopoulos and Karayiannis, 2005, for an evaluation of the general impact of Thomas Kuhn and Imre Lakatos on ideas relating to the development of economic theories). But we would like to specify two points. Kesting (2005) emphasizes the similarities as well as differences between the ideas of Schumpeter and Kuhn. He also underlines that both were in Harvard University when they asserted their views without notice each other. It is surprising, however, that Backhouse (1996) argued that Schumpeter's views on 
Yay Turan (2021), Method and scope in Joseph A. Schumpeter's economics: a pluralist perspective, The Journal of Philosophical Economics: Reflections on Economic and Social Issues, XIV (1-2), 63-107

economic methodology and the sociology of science are outdated. When we look at the whole of the Schumpeter's works, we cannot say that he is a criterionseeking economist for deciding what is scientific and what is not scientific. But he emphasized the importance of logical consistency and empirically testability, as today's economists did (Schumpeter 1991b). It is interesting that Backhouse's proposal to economists ('recovering practice') corresponds to what Schumpeter deal with during all of his academic career: the importance of 'intellectual, cultural and historical considerations in understanding of economic practice' (de Marchi 1997, p.12).

\section{References}

Arena, Richard and Véronique Dutraive (2016), 'Industrial economics and policy: recent history and theoretical foundations', Revue D'économie Industrielle, 154, 33-61.

Backhouse, Roger E. (1996), 'Vision and progress in economic thought: Schumpeter after Kuhn', in Laurence S. Moss (ed) Joseph A. Schumpeter: Historian of Economics, London: Routledge, pp.21-32.

Backhouse, Roger E. (2010), 'Methodology in action', Journal of Economic Methodology, 17 (1), 3-15.

Baumol, William J. (1968), 'Entrepreneurship in economic theory', American Economic Review, 58(2), 64-71.

Baumol, William J. (1990), 'Entrepreneurship: productive, unproductive and destructive', Journal of Political Economy, 98(5), 893-921.

Becker, Markus C., Thorbjorn Knudsen (2003), 'The entrepreneur at a crucial juncture in Schumpeter's work: Schumpeter's 1928 handbook entry entrepreneur', in Roger Koppl (ed.), Advances in Austrian Economics, 6, Elsevier Science Ltd., 199-233.

Bögenhold, Dieter (2017), 'The order of social sciences: sociology in dialogue with neighbouring disciplines', The Journal of Philosophical Economics: Reflections on Economics and Social Issues, XI(1), 27-52. 
Yay Turan (2021), Method and scope in Joseph A. Schumpeter's economics: a pluralist perspective, The Journal of Philosophical Economics: Reflections on Economic and Social Issues, XIV (1-2), 63-107

Bögenhold, Dieter (2018a), 'Economics between insulation and socialscienciation: observations by a sociology of economics', Journal of Economic Issues, LII (4), 1125-1142.

Bögenhold, Dieter (2018b), 'Schumpeter's split between "pure" economics and institutional economics: why methodological individualism was not fully considered', International Advances in Economic Research, 24(3), 253-264.

Böhm-Bawerk, Eugen von ([1891] 1930), Positive Theory of Capital, New York: G. E. Stechert Co.

Caldwell, Bruce ([1982] 1994), Beyond Positivism: Economic Methodology in the Twentieth Century, New York: Routledge.

Cedrini, Mario and Stefano Fiori (2016), 'Shifting boundaries, within and outside economics', History of Economic Ideas, 24(3), 11-28.

Clark, John B. ([1915] 2007), Essentials of Economic Theory, Auburn Alabama: Ludwig von Mises Institute.

Davis, John B. (2006), 'The turn in economics: neoclassical dominance to mainstream pluralism?', Journal of Institutional Economics, 2(1), 1-20.

Davis, John B. (2014), 'Pluralism in economics a symposium', Review of Political Economy, 26 (4), 477- 478.

Davis, John B. (2016), 'Economic imperialism versus multidisciplinary', History of Economic Ideas, 24(3), 77-94.

Davis, John B. (2019), 'Specialization, fragmentation, and pluralism in economics', The European Journal of the History of Economic Thought, 26(2), 271-293.

De Marchi, Neil (1988), The Popperian Legacy in Economics, Cambridge MA: Cambridge University Press.

De Marchi, Neil (1992), Post-Popperian Methodology of Economics: Recovering Practice, Boston: Kluwer Academic Publishers.

Dow, Sheila C. (2008), 'Plurality in orthodox and heterodox economics', The Journal of Philosophical Economics, I (2), 73-96. 
Yay Turan (2021), Method and scope in Joseph A. Schumpeter's economics: a pluralist perspective, The Journal of Philosophical Economics: Reflections on Economic and Social Issues, XIV (1-2), 63-107

Drakopoulos, Stavros A., Anastassios D. Karayiannis (2005), 'A review of Kuhnian and Lakatosian explanations in economics', History of Economic Ideas, 13 (2), 51-73.

Dutt, Amitava Krishna (2014), 'Dimensions of pluralism in economics', Review of Political Economy, 26 (4), 479- 494.

Ebner, Alexander (2000), "Schumpeter and the "Schmollerprogramm": integrating theory and history in the analysis of economic development', Journal of Evolutionary Economics, 10, 355-372.

Ekelund, Robert B., Hebert, Robert F. (1990), A History of Economic Thought and Method, Third edition, New York: McGraw Hill Publishing Company.

Festré, Agnes, Odile Lakomski-Laguerre and Stephane Longuet (2017), 'Schumpeter and Schumpeterians on economic policy issues: re-reading Schumpeter through the lens of institutional and behavioral economics. An introduction to the special issue', Journal of Evolutionary Economics, 27, 3-24.

Garnett, Robert, Erik K. Olsen, and Martha Starr (eds.) (2010), Economic Pluralism, Routledge.

Haberler, Gottfried (1951), 'Joseph Alois Schumpeter', in Seymour E. Harris (ed.), Schumpeter: Social Scientist, Cambridge: Harvard University Press, pp.24-47.

Hahn, Frank (1984), Equilibrium and Macroeconomics, Oxford: Basil Blackwell.

Hanusch, Horst and Andreas Pyka A (2007a), 'Schumpeter, Joseph Alois (18831950)' in H. Hanusch, A. Pyka (eds.) Elgar Companion to Neo-Schumpeterian Economics, Cheltenham UK: Edward Elgar, pp.19-26

Hanusch, Horst and Andreas Pyka A (2007b), 'Manifesto for comprehensive neo-Schumpeterian economics', History of Economic Ideas, 15(1), 23-41.

Hayek, Friedrich August von ([1931] 1960), Prices and Production, Second Edition, Great Britain: Routledge Kegan Paul Ltd.

Hebert, Robert F., and Albert N. Link (2006), Historical Perspectives on the Entrepreneur, Hanover, MA: Now Publishers. 
Yay Turan (2021), Method and scope in Joseph A. Schumpeter's economics: a pluralist perspective, The Journal of Philosophical Economics: Reflections on Economic and Social Issues, XIV (1-2), 63-107

Heise, Arne (2020), 'Comparing economic theories or pluralism in economics and the need for a comparative approach to scientific research programmes', The Journal of Philosophical Economics, 13(2), 162-184.

Janik, Allan and Stephen Toulmin (1973), Wittgenstein's Vienna, New York: A Touchstone Book published by Simon and Schuster.

Kellert, Stephen H., Helen E. Longino and C. Kenneth Walters (eds.) (2006), Scientific Pluralism, Minneapolis: University of Minnesota Press.

Kesting, Peter (2005), 'Vision, revolution, and classical situation: Schumpeter's theory of scientific development', History of Economics Review, 41(1), 77-97.

Kesting, Peter (2006), 'The interdependence between economic analysis and methodology in the work of Joseph A. Schumpeter', The European Journal of the History of Economic Thought, 13(3), 387-410.

Kirzner, Israel M. (1997), 'Entrepreneurial discovery and the competitive market process: an Austrian approach.', Journal of Economic Literature, 35(1), 60-85.

Kirzner, Israel M. (1999), 'Creativity and/or alertness: a reconsideration of the Schumpeterian entrepreneur', Review of Austrian Economics, 11, 5-17.

Knight, Frank H. ([1921] 1964), Risk, Uncertainty and Profit, New York: Augustus M. Kelley, Bookseller.

Kuhn, Thomas ([1962] 1996), The Structure of Scientific Revolutions, Third Edition, Chicago: The University of Chicago Press.

Lavoie, Don (1985), Rivalry and Central Planning: Socialist Calculation Debate Reconsidered, Cambridge: Cambridge University Press.

Lazear, Edward, P. (2000), 'Economic imperialism', The Quarterly Journal of Economics, 115(1), 99-146.

Legrand, M. D. Pont, and Harald Hagemann (2017), 'Business cycles, growth and economic policy: Schumpeter and the Great Depression', Journal of the History of Economic Thought, 39(1), 19-33. 
Yay Turan (2021), Method and scope in Joseph A. Schumpeter's economics: a pluralist perspective, The Journal of Philosophical Economics: Reflections on Economic and Social Issues, XIV (1-2), 63-107

Machlup, Fritz (1951), 'Schumpeter's economic methodology', in S. E. Harris (1951) Schumpeter: Social Scientist, Cambridge MA: Harvard University Press, pp. 95-100.

Maki, Uskali (1997), 'The one world and the many theories', in A. Salanti and E. Screpanti (eds) Pluralism in Economics, Cheltenham: Edward Elgar, pp.37-47.

Maki, Uskali (2009), 'Economics imperialism: concept and constraints', Philosophy of the Social Sciences, 39(3), 351-380.

Malerba, Franco and Luigi Orsenigo (1995), 'Schumpeterian patterns of innovation', Cambridge Journal of Economics, 19, 47-65.

Malerba, Franco (2005), 'Innovation and the evolution of industries', Journal of Evolutionary Economics, 16, 3-20.

Malerba, Franco and Maureen McKelvey (2020), 'Knowledge-intensive innovative entrepreneurship: integrating Schumpeter, evolutionary economics, and innovation systems', Small Business Economics, 54. 503-522.

Marchionatti, Roberto and Mario Cedrini (2017), Economics as Social Science: Economics Imperialism and the Challenge of Interdisciplinarity, Routledge.

Marqués, Gustova and Diego Weisman (2010), 'Is Kuhnean incommensurability a good basis for pluralism in economics?', in Garnett, Robert, Erik K. Olsen and Martha Starr (eds.) Economic Pluralism, Routledge, pp.74-86.

Mathews, John A. (2007), 'Reflections on Schumpeter's "lost" seventh chapter to the theory of economic development', in H. Hanusch, A. Pyka (eds.) Elgar Companion to Neo-Schumpeterian Economics, Cheltenham: Edward Elgar, pp.78-96.

McCaffrey, Matthew (2013), 'Conflicting views of the entrepreneur in turn-ofthe-century Vienna', History of Economic Review, 58, 27-43.

Meerhaeghe, Marcel A. G. van (2003), 'The lost chapter of Schumpeter's economic development', in Jürgen Backhaus, (ed.) Joseph Alois Schumpeter: Entrepreneurship, Style and Vision, Boston: Kluwer Academic Publishers, pp. 233-244. 
Yay Turan (2021), Method and scope in Joseph A. Schumpeter's economics: a pluralist perspective, The Journal of Philosophical Economics: Reflections on Economic and Social Issues, XIV (1-2), 63-107

McCraw, Thomas K. (2007), Prophet of Innovation: Joseph Schumpeter and Creative Destruction, Cambridge: Belknap Press of Harvard University Press.

Mises, Ludvig von ([1949] 1998), Human Action: A Treatise on Economics, Auburn, Alabama: Ludwig von Mises Institute.

Moura, Mario da Graça (2002), 'Metatheory as the key to understanding: Schumpeter after Shionoya', Cambridge Journal of Economics, 26, 805-826.

Osterhammel, Jürgen (1989), 'Varieties of social economics: Joseph A. Schumpeter and Max Weber', in J. M. Wolfgang, J. Osterhammel (eds.), Max Weber and His Contemporaries, London and New York: The German Historical Institute, Routledge Taylor \& Francis Group, pp.106-120.

Peneder, Michael and Andreas Resch (2021), Schumpeter's Venture Money, Oxford: Oxford University Press.

Peukert, Helge (2003), 'The missing chapter in Schumpeter's: the theory of economic development', in Jürgen G. Backhaus (2003) (ed.), Joseph Alois Schumpeter: Entrepreneurship, Style and Vision, Kluwer Academic Publishers, pp.221-232.

Schulak, Eugen Maria and Herbert Unterköfler (2011), Austrian School of Economics: A History of Its Ideas, Ambassadors, and Institutions, Auburn: Mises Institute.

Schumpeter, Joseph A. ([1908] 2010), The Nature and Essence of Economic Theory, New Brunswick and London: Transactions Publishers.

Schumpeter, Joseph A. ([1911] 2002), 'Seventh chapter of the theory of economic development (The economy as a whole)', translator Ursula Backhaus, Industry and Innovation, 9 (1-2), 93-145.

Schumpeter, Joseph A. ([1912] 1954), Economic Doctrine and Method: An Historical Sketch, New York: Oxford University Press.

Schumpeter, Joseph A. (1928), 'The instability of capitalism', Economic Journal, 38(151), 361-386.

Schumpeter, Joseph A. (1933), 'The common sense of econometrics', Econometrica, 181, 5-12. 
Yay Turan (2021), Method and scope in Joseph A. Schumpeter's economics: a pluralist perspective, The Journal of Philosophical Economics: Reflections on Economic and Social Issues, XIV (1-2), 63-107

Schumpeter, Joseph A. ([1934] 1963), The Theory of Economic Development, New York: Oxford University Press.

Schumpeter, Joseph A. (1937), 'Preface to Japanese edition of Theorie der Wirtschaftlichen Entwicklung', in Richard V. Clemence (1951), Essays of J. A. Schumpeter, Addison-Wesley Press, Inc., pp.158-163.

Schumpeter, Joseph A. (1939), Business Cycles: A Theoretical, Historical and Statistical Analysis of the Capitalist Process, New York: MacGraw Hill Book Company.

Schumpeter, Joseph A. ([1943] 2003), Capitalism, Socialism and Democracy, London: Routledge.

Schumpeter, Joseph. A. ([1954] 1986), History of Economic Analysis, London: Routledge.

Schumpeter, Joseph A. (1991), 'Recent developments of political economy', in R. Swedberg, (1991), pp. 284-315.

Schumpeter, Joseph A. (1991b), 'The meaning of rationality in the social sciences', in Richard Swedberg (1991), pp. 316-338.

Schumpeter, Joseph A. (2003), 'Entrepreneur', in Roger Koppl (ed.), Advances in Austrian Economics, Volume 6, Elsevier Science Ltd., pp. 235-265.

Sent, Esther-Mirjham (2006), 'Pluralisms in economics', in Stephen H. Kellert, Helen E. Longino and C. Kenneth Walters (eds.), Scientific Pluralism, Minneapolis: University of Minnesota Press, pp.80-101.

Shionoya, Yuichi (1990a), 'The origin of the Schumpeterian research program: a chapter omitted from Schumpeter's theory of economic development', Journal of Institutional and Theoretical Economics 146, 314-327.

Shionoya, Yuichi (1990b), 'Instrumentalism in Schumpeter's economic methodology', History of Political Economy, 22(2), 187-222.

Shionoya, Yuichi (1997), Schumpeter and the Idea of Social Science, Cambridge: Cambridge University Press. 
Yay Turan (2021), Method and scope in Joseph A. Schumpeter's economics: a pluralist perspective, The Journal of Philosophical Economics: Reflections on Economic and Social Issues, XIV (1-2), 63-107

Shionoya, Yuichi (2000), 'Joseph Schumpeter and the German Historical School', in Peter Koslowski, (ed.), The Theory of Capitalism in the German Economic Tradition, Berlin Heidelberg: Spirnger-Verlag, pp.3-23.

Shionoya, Yuichi (2012), 'Joseph Alois Schumpeter: economist of rhetoric', in Jürgen G. Backhaus, (ed.), Handbook of the History of Economic Thought, Heidelberg and New York: Springer, pp. 581-604.

Swedberg, Richard (1991), J. A. Schumpeter: The Economics and Sociology of Capitalism, New Jersey: Princeton University Press.

Swedberg, Richard (1993), Joseph A. Schumpeter: His Work and Work, Cambridge UK: Polity Press.

Weber, Max (1949), The Methodology of the Social Sciences, A. Edward, E.A. Shills, A. Henry, H.A. Finch (eds. and translators), Glencoe, Illinois: The Free Press.

Weintraub, E. Roy (2002), How Economics Became a Mathematical Science, London: Duke University Press.

Wieser, Friedrich von (1927), Social Economics, New York: Adelphi Company.

Zweig, Stefan (2013), The World of Yesterday: An Autobiography, Lincoln, and London: University of Nebraska Press.

Turan Yay is Professor at Yeditepe University, Dept. of International Trade \& Business, İstanbul (Turkey) (turan.yay@yeditepe.edu.tr). 